\title{
Commentary: Intimate Memories and Coping with World War II Internment
}

\author{
Harold Mytum
}

Accepted: 23 January 2017 / Published online: 27 August 2018

(C) The Author(s) 2018

The essays in this thematic issue offer exciting new insights into the experience of internment and include some innovative methodological approaches to this aspect of "painful heritage." The material in these papers also throws light on some issues that are not the direct focus of these studies, but relate to experiences of both those involved with internment at the time, of survivors and descendants, and of contemporary researchers. Using the evidence and arguments presented here from Amache, Monticello, and Kooskia, and combining this with experiences from elsewhere, not only in North America, but also Europe and the Pacific, it is possible to discern some significant patterns that frame archaeological research on these types of sites. The reflections here can be articulated under a series of four headings: coping strategies during internment; remembering, forgetting, and coping in peacetime; archaeology, oral history, and re-membering; and archaeology and embodying the internment experience. Larger issues come out of the particular, when the biographies of places, families, and individuals relating to internment are examined. This is how I have explored internments on the Isle of Man in both World Wars (Mytum 2011, 2012, 2013b), as the scholars here are examining distinctive forms of imprisonment during World War II in the United States in their chosen locations for study. Taking a comparative

\section{H. Mytum $(\bowtie)$}

Department of Archaeology, Classics and Egyptology, University of Liverpool, 12-14 Abercromby Square, Liverpool L69 7WZ, UK

e-mail: hmytum@liv.ac.uk approach to the particular studies offers a different perspective, particularly when placed in the wider developing academic interests in memory, coping with difficult pasts, and the creation of identities in a globalized world that have promoted family history.

\section{Coping Strategies during Internment}

Internment was an unexpected dislocation of people's lives through forces beyond their control. People were socially and physically uprooted and placed in unaccustomed surroundings and conditions. These were stressful times, not helped by their exclusion from the world for an indeterminate period. A few individuals were not able to adjust to new circumstances, and their physical or mental health suffered from what was often termed "barbed wire disease" (Vischer 1919). Most internees reacted by employing a series of coping strategies that both individually and communally created mechanisms of adaptation. For some time, medical and social science researchers have been interested in how 20th-century people coped with incarceration (McCrae 1984; Somerfield and McCrae 2000); the military has used this information to prepare armed forces for conditions under capture by the enemy (Ursano and Rundell 1995).

The archaeological dimension to an analysis of coping strategies brings the ways in which both portable material culture and fixed elements, such as structures and landscape features, were employed in 
coping strategies (Mytum 2013b); indeed, the powerful associative power of artifacts with survivors is in no small part due to their role in managing internment. Authorities were often concerned to avoid the "barbed wire disease" first identified during World War I and, so, were supportive of many activities that kept morale high and prevented either insurrection or costly health interventions. This was achieved by provision of resources and facilities for activities, and acceptance of physical changes within the camp that would not have been tolerated within a typical military context. There are some significant differences in coping strategies between military prisoners in single-sex camps, as at Monticello, and civilian camps with people of different ages and sexes, as with Amache, but a remarkable number of the strategies are independently but similarly achieved in disparate locations and contexts, revealing underlying reservoirs of shared cultural knowledge and adaptive strategies.

Hosken and Tiede (this issue) invoke Silliman's (2001:195) concept of "survivance," the "creative responses to difficult times, or agentive actions through struggle," which is part of the repertoire of coping, together with resistance in its more or less overt forms. Resistance is not a theme emphasized in the articles here, though it is often evoked in internment studies relating to both civilian (Carr 2012; Burton and Farrell 2013) and military (Doyle et al. 2013) contexts. This is often placed in opposition to collaboration, another form of coping, but in most cases the situation was much more fluid and nuanced, and perhaps accommodation is an appropriate term, as all-both authorities and internees - adjusted behaviors and attitudes in order to get through this indeterminate, but ultimately finite, period (Henshaw 2012). The Kooskia inmates outwardly conformed to many forms of the dominant American culture, including holding Independence Day celebrations, but also retained and maintained Japanese traditions (Hosken and Tiede, this issue). Collaboration or resistance is a binary opposition that does not easily define or explain how survivance was achieved through a wide range of sometimes apparently incompatible coping strategies.

It can be difficult to disentangle motivations of identity retention as coping in the form of survivance or resistance (and indeed they could be read and interpreted by all in various ways as moods and attitudes changed over time). Japanese Americans largely attempted to appear American whilst retaining certain Japanese traits, such as gardens (Beckwith 2013; Clark, this issue) or sake drinking (Slaughter 2013), but in other situations alienation increased during internment (Kewley Draskau 2012). Whilst identity maintenance could be a major coping strategy-usually national identity, but sometimes religious, class, or family identity - other strategies were also employed within a camp. These gave internees a focus for their attention, allowed them to associate together toward a common end, and could absorb that resource of which there was almost unlimited supply-time. Many of these activities can be seen as rituals of cooperation (Sennett 2012; Barnes, this issue), part of coping with living in physically and socially constrained spaces. The pattern of sporting, artistic, and educational endeavors can be seen in all internment contexts from World War I onward, revealing similar responses to similar circumstances from people whose normal lives were dominated by domestic or wage labor. Leisure and educational opportunities were then more limited than today, so internees took advantage of the chance to express themselves and fulfill aspects of personal development that would have been impossible in normal circumstances. Whilst many lives were stunted by internment, for others it was a chance to discover aspects of their character and skills that they did not know about. Many Monticello soldiers learned to read, or to speak new languages, only because of internment (Barnes, this issue; Bizio, this issue).

Coping strategies were conceptualized and implemented at individual, familial, and community levels, with or without the support or tacit acceptance of the authorities. The papers in this thematic issue reveal some of the different strategies, motivations, and archaeologists' interpretations of these and demonstrate that further research on coping strategies - and in particular the role of material culture and practices that create and recreate landscapes and artifacts within such strategies - is a rich field that will be of value beyond archaeology and to the wider social and behavioral sciences.

\section{Remembering, Forgetting, and Coping in Peacetime}

One of the most notable features of the peacetime attitudes and activities of the interned is one of forgetting. In what might now be considered a form of post- 
traumatic stress disorder (PTSD), there could be many effects that could last decades, including isolation, guilt, and obsessive behaviors. Studies that compared Vietnam War veterans with those from World War II have shown that PTSD can be long lasting (Query et al. 1986; Zeiss and Dickman 1989). For veterans, there was often anxiety about one's place in a world that was healing divisions when one's own role in the conflict was seen as problematic. The nature of that liminal position applies to both military and civilians, but with potentially different reactions to the sufferings by the wider population. Some military prisoners were seen as heroes, as in the UK and U.S.A., but others were accused of being cowards for having surrendered; Russian prisoners returned from Norway were sent to execution squads or gulags under the Stalinist regime (Jasinski 2013). In a few contexts civilian internees were also lauded (Carr 2014), but most, remaining in the countries that had incarcerated them under various forms of xenophobia, largely chose to be silent and attempted rapid integration to the point where any such remaining antipathy would be minimized. Bizio (this issue) notes that her father was not happy to talk about his imprisonment, and that was widespread amongst Japanese Americans in North America (Nagata and Cheng 2003) and Jews in Britain (Ulmschneider and Crawford 2013). It is only in recent years that those involved who are still alive wished to tell their stories, after sufficient time had passed and when integration seemed assured. The growing fashion for family history can be satisfied whilst unburdening a difficult past in the more secure psychological and social environment that has developed in peacetime, and archaeologists can benefit from this (Jasinski and Sem 2015). Bizio (this issue) and Fujita (this issue) reflect that trend, one that historical archaeologists have recognized and integrated within their research programs to great effect, not only in North America, but across many parts of the globe affected by World War II. Significantly, perhaps, the same trend has yet to be seen for the Korean, various British or other European end-of-empire, or Vietnamese conflicts. Research on some of these may soon benefit from this integrated approach; already the material remains of structures and artifacts from up to and including the Cold War now attract archaeological study and even heritage protection.

Connerton (2008) has explored the process of forgetting and the positive value that forgetting has for individuals and communities. This is a key element of all our lives, sifting what we wish to hold in our minds and that which we lose in order to focus on the world in which we live and act. Interested in the past, we give primacy to the remembered, but we need to appreciate how this is a subset of total experiences and feelings most of which has been forgotten. Of course, much is also retained, but not easily recovered, and some of the archaeological projects, including showing artifacts to survivors, facilitate that surfacing of long-suppressed memories. However, that surfacing, like the recovery of a buried artifact, is not of a pristine recollection, but one distorted by time, later experiences, and information, and is expressed in the present in very particular social and cultural contexts.

Connerton (2008) identified seven forms of forgetting, and it is worth briefly outlining them here, with a focus on those most relevant to post-internment realignment. Repressive erasure could be seen in the demolition of camps and the removal of all easily visible traces of internment, but these processes were more part of a postwar return to normality. The official omission of the Japanese American experience from the dominant war narrative could be seen as repressive erasure, but this is better seen as prescriptive forgetting, thought to be in the best interest of all parties. The state and all nationalities within the country were more likely to heal and move to peacetime closure if all were forgotten. This may be the type of forgetting supported by the cattle owner whose animals graze at Amache; bad things happened there that should be forgotten (Clark, this issue). There may be contemporary interests that justify that view, but these are no different from the vested interests of those who wish to revive memories. Remembering may reopen social divisions, a danger recognized by those managing and researching the heritage of the Northern Ireland conflicts (Horning 2006). Moshenska (2008) highlights that there are ethical implications of our work as archaeologists, which means that bringing the past into the present has consequences of which we should be aware before we begin. Structural amnesia is where aspects of one's genealogy are forgotten in favor of others. The traditional taking of a man's surname on marriage and children taking that name, in effect, over generations, prioritized some aspects of identity over others. Structural amnesia may have been important to post-internment communities and was certainly so to the many Europeans settling in Australasia, Britain, or North America who Anglicized or completely changed their names. It has often been the second or even third generation, now fully integrated and confidently 
belonging to the state within which they live, that wishes to discover its complex and multicultural roots.

Forgetting as annulment is coping with too much data, and data that are no longer culturally useful. This can be seen, for example, in great debates in archaeological theory. My students no longer know or care about the culture historians vs. new archaeologists, or the post-processualist arrival. These debates sit in journals, now available electronically, that students rarely see due to a single efficiency decision by commercial journal publishers accustomed to a 10-year cut-off point for scientific journals and their easy accessibility. A case in point is Post-Medieval Archaeology, available electronically for all issues under Maney Publishing, now generally available only from 1997 after being taken over by Taylor \& Francis (though this is being discussed with the publishers). In relation to internment, large amounts of official documentation were destroyed in the later decades of the 20th century as part of the ongoing process of government data management and, sadly, are not available now for scholars. Artifacts and memorabilia have been discarded on the deaths of internees, and this process no doubt continues, as it is only members of that subset now researching their family history who place value on these assemblages; it is a biased subset that interacts with historical archaeologists.

Forgetting as planned obsolescence is a process we historical archaeologists study, and these changes mean that we must forget old ways of doing to take on new ones. What use to an internee in a postwar world were all of the key social and practical skills honed in an enclosed, overcrowded camp with limited interaction with the wider community and world? Much became obsolete and was discarded. Other items were hidden; only now are artifacts, photographs, and diaries being extracted from attics and returned to a socially and culturally significant place in identity formation in the globalized $21 \mathrm{st}-$ century context, though with values and meanings potentially very different from those they held when in the camps. Finally, forgetting as humiliated silence seems to relate to many aspects of the forgetting - both by the state and by those who suffered the experience. Just as the 10 million men across Europe maimed from World War I received no recognition, whilst the human (but not animal) war dead were annually remembered at ceremonies and memorials, so internees and other groups were in humiliated silence (Mytum 2013a). Again, it is only in recent years that groups both in the U.S. and Britain have campaigned for these silences and forgettings to be remedied, with the proliferation of memorials in Washington, and in the UK at the National Memorial Arboretum, being the material representation of this ending of collective forgetting (Williams 2014; Login 2015).

\section{Archaeology, Oral History, and Re-membering in the 21st Century}

Across the globe, the centenary events associated with World War I roll on, as not only European nations, but also ex-colonies, such as Australia and New Zealand, remember the catalog of losses from Mons and Ypres of 1914 through the Dardanelles in 1915 and Verdun and Jutland in 1916, to Messines in 1917 and Amiens of 1918. It is notable how both remembrance and academic study for this global conflict is notably different from that conducted for World War II, where oral history and direct experience of at least some of the events can have a human as well as documentary and artifactual element. Moreover, as World War II had a far greater impact on civilians than earlier conflicts, the range of events, experiences, and memories-and therefore places and objects of significance - are more diverse in type and more geographically dispersed. These essays examine civilian internees and military prisoners of war in places where they were confined, places that were far from the fields of conflict. These are not the stories and memories of fighting, destruction, and death, but ones of dislocation, separation, alienation, incarceration that form part of the rich and multilayered experiences of those caught up in the global conflict of World War II.

There are still a few people alive today who experienced World War II internment, though they were children, and they have a particular lens through which those direct memories were collected. Throughout their lives, their parents could have provided additional perspectives of their families' experiences, but this was often not a topic that was recollected. However, this focus on remembrance needs to be deconstructed, just as the ways in which sites are publicly interpreted today require reflexive treatment (Roxworthy 2008). The internees of 
earlier conflicts are now largely seen through official documents; personal records, such as letters and diaries; and material culture that may or may not be recovered through archaeological fieldwork. Archaeologists have investigated internee experiences during the U.S. Civil War, the Napoleonic campaigns, and World War I, always using a wide range of sources (Mytum and Carr 2013), but the greatest amount of recent work has been on World War II, no doubt in part because some element of survivor testimony can still be applied.

Clark (this issue) highlights the importance of artifacts in remembering. To an archaeologist, an artifact is a prompt to memories, and it carries emotional connections that may be appreciated by the person who saw or used that item in its original context. Descendants may also form an emotional link with artifacts. These different perspectives of war memorabilia today have been noted elsewhere (Moshenska 2006), and, indeed, all who work with descendants and their family heirlooms underscore the complex layers of value that give them significance to their owners. Archaeological practices and perspectives need to be sensitive to this intersubjectivity, which will add to the differences of perspective or interpretation. Selective memory and selective forgetting are inevitable parts of that re-membering. Just as archaeological fieldwork is not a pure empirical process, remembering is not a form of data retrieval like opening a document on a computer. Memories are reinforced, modified, adapted-sometimes consciously but often unconsciously - as time and context changes. Indeed, as descendants come to wish to meet and remember times long ago, their shared re-memberings create new associations. Memories can be retrieved or created by viewing photographs or documents. Through this process, personal memory merges into collective memory (Connerton 1989), and, as the last survivors die, it is this evolving and usually multistranded collective memory that becomes the remembered form that archaeologists themselves affect by their research. As archaeologists, our actions create expressions of past actions and feelings, but in the present. They have the ethnographic and psychological equivalent of taphonomic processes that apply to the material world. The challenge of archaeology may be not only to overcome official forgetting of, say, Japanese American experiences during World War II and the selective collective memory created by mainstream narratives. It may also be to provide alternative narratives to those of the few remaining internees and their descendants, and there are substantial ethical issues here as to how and why we should carry out such projects (Moshenska 2006, 2010; Mytum 2015). Here archaeology comes face to face not only with the past, but also with how many diverse groups wish to remember and interpret that past in the present, even more starkly revealed in the even more harsh contexts of the Holocaust (Myers 2008), the Spanish Civil War (González-Ruibal 2007), or Northern Ireland (McAtackney 2011).

\section{Archaeology and Embodying the Internment Experience}

Internment was, above all, a physical containment, and one where the bodily functions were both paramount in camp design and management, and in the structuring of daily lives. These were made all the more visible by the limitations on privacy in the densely occupied and highly controlled spaces that were the camps. In this sense, coping emphasizes the psychological pressures and the embodying highlights the physical aspects of internment (Mytum 2013c).

Food, across all forms of internment in all locations, was an obsession. Sometimes, as with Allied prisoners of war in the Far East, this was due to malnourishment, but in most cases it was a combination of a limited repertoire of ingredients and the cultural mismatch between supplies and traditional cuisines. Thus, the desire for pasta, tomatoes, and caffe latte at Monticello (Barnes, this issue), and the importance of rice-for food and sake - at Amache (Shew and Kamp-Whittaker 2013; Slaughter 2013) may seem to feed into racial stereotypes, but it also reflects the desire for normality and the importance of eating and drinking in maintaining morale. The tea leaves scattered on the Amache gardens (Clark, this issue) again point to highly significant and distinctive behaviors that maintained and enhanced social cohesion. Having some control over food, menus, drinking patterns, and the social structuring associated with these activities gave the internees some power over their lives. Just as an army marches on its stomach, so internees fill their time as well as their stomachs with the meals, which punctuate the day and are one of the few structuring elements that can 
be anticipated from hour to hour. Moreover, whether in the household Japanese American kitchens or those for the canteens seen across all camps, internees were involved in food preparation, cooking, and in the clearing and washing up. This enacting of everyday aspects of labor gave purpose to those involved, a sense of achievement.

The overcrowding seen in Fujita's reminiscences is widespread in internee accounts. Adults would have found not only the overcrowding, but also the lack of options in social interactions, unfamiliar and stressful. In addition, boredom and the increased frustrations and lowering of toleration of neighbors were assuaged, where possible, through actions. Keeping the body busy was essential and achieved through many forms of activity, from landscape manipulation and gardening, crafts, sports, and artistic creativity of all kinds. The importance of some of the products of these activities is indicated by the number of items retained after the camps were abandoned. Craft items or documents indicating camp activities, such as concert or drama programs, materially fix the experience and allow it to be held and seen immediately after internment and over the decades since.

The internees at the Kooskia labor camp left a physical impact on its forested landscape (Hosken and Tiede, this issue). Enhanced by the absence of barbed wire and guard towers, the lack of obvious containment and observation created a more positive environment. Other camps allowed gardening and farmwork beyond their confines, but to a lesser extent, and the wire remained a potent symbolic indicator of constraint as it has in many other contexts (Carr and Mytum 2012; Persson 2014). Those with useful professional skills - such as the dentists at Kooskia-could concentrate their attention on services to the camp community and, in the process, also preserve for themselves a status, a role, a relevance, and, indeed, a physical place in a recognizable location of employment. Likewise, the Monticello military maintained its internal structure and retained the significance of wearing military uniforms and medals on appropriate occasions (Barnes, this issue). Both dentists and soldiers used clothing - white coats or uniforms - to indicate their distinctiveness and identity through bodily appearance. All, including the Japanese American civilians, were visibly distinct from the camp guards with their uniforms.

\section{Conclusions}

This special issue is a significant contribution to the developing field of conflict archaeology that looks beyond the battlefield to the many other aspects of war that affected the lives of numerous groups well away from the front line. It reveals research that lies at the intersection of memory studies, family history, oral history, conflict archaeology, community, and public archaeology. The voices of those whose material world we archaeologists recover speak to us directly and indirectly, through survivors, descendant families, and others in the neighboring communities. We are on the cusp of losing the direct oral testimony from internees and the communities onto which they were imposed during World War II. Adding these insights into their material worlds and practices is central to understanding the evidence we recover. We ask different questions of former internees and their descendants, and their answers add to the numerous strands of data that come together to reveal complex, contradictory, and nuanced contexts of internment. Past reticence - for some at least - is now being broken, and archaeologists are now aware of the cultural significance of these places of incarceration and the structures, landscapes, and artifacts they contain. The research reported here reveals the past, makes that past relevant to a diverse range of audiences in the present, and provides plentiful evidence for why these resources require protection and sensitive management into the future. Industrial archaeologists have increasingly recorded the declining traditional industries in human as well as material terms (Badcock and Malaws 2004; Shackel 2004), whilst being aware of how what we do has an impact on collective memory (Barthel 1996). New theoretical approaches, including relational ones that incorporate agency of material things as well as people and large societal structures, may be one way of accommodating all these strands (Mytum 2013b).

Many aspects of the 20th century are or will soon be on a memory cusp and also require attention. These essays can encourage historical archaeologists to be proactive in reaching out to the relevant communities and survivors. Only then can the particular qualities of study possible when those active in such times and places can be involved be applied to other important aspects of the recent past. This issue thus contributes to the archaeologies of World War II, but also to other archaeologies of the later 20th century. 
Open Access This article is distributed under the terms of the Creative Commons Attribution 4.0 International License (http:// creativecommons.org/licenses/by/4.0/), which permits unrestricted use, distribution, and reproduction in any medium, provided you give appropriate credit to the original author(s) and the source, provide a link to the Creative Commons license, and indicate if changes were made.

\section{References}

Badcock, Anna, and Brian Malaws

2004 Recording People and Processes at Large Industrial Structures. In The Archaeology of Industrialization, Society for Post-Medieval Archaeology Monograph 2, David Barker and David Cranstone, editors, pp. 269-289. Maney, Leeds, UK.

Barthel, Diane

1996 Getting in Touch with History: The Role of Historic Preservation in Shaping Collective Memories. Qualitative Sociology 19(3):345-364.

Beckwith, Ronald J.

2013 Japanese-Style Ornamental Community Gardens at Manzanar Relocation Center. In Prisoners of War: Archaeology, Memory, and Heritage of 19th- and 20th-Century Mass Internment, Harold Mytum and Gilly Carr, editors, pp. 271-284. Springer, New York, NY.

Burton, Jeffrey F., and Mary M. Farrell

2013 "Life in Manzanar Where There Is a Spring Breeze": Graffiti at a World War II Japanese American Internment Camp. In Prisoners of War: Archaeology, Memory, and Heritage of 19th- and 20th-Century Mass Internment, Harold Mytum and Gilly Carr, editors, pp. 239-269. Springer, New York, NY.

Carr, Gilly

2012 'God Save the King!' Creative Modes of Protest, Defiance and Identity in Channel Islander Internment Camps in Germany, 1942-1945. In Cultural Heritage and Prisoners of War: Creativity behind Barbed Wire, Gilly Carr and Harold Mytum, editors, pp. 168-185. Routledge, New York, NY.

Carr, Gilly

2014 Legacies of Occupation. Springer, New York, NY.

Carr, Gilly, and Harold Mytum (editors)

2012 Cultural Heritage and Prisoners of War: Creativity behind Barbed Wire. Routledge, New York, NY.

Connerton, Paul

1989 How Societies Remember. Cambridge University Press, Cambridge, UK.

Connerton, Paul

2008 Seven Types of Forgetting. Memory Studies 1(1):59-72.

Doyle, Peter, Jamie Pringle, and Lawrence E. Babits

2013 Stalag Luft III: The Archaeology of an Escaper's Camp. In Prisoners of War: Archaeology, Memory, and Heritage of 19th- and 20th-Century Mass
Internment, Harold Mytum and Gilly Carr, editors, pp. 129-142. Springer, New York, NY.

González-Ruibal, Alfredo

2007 Making Things Public: Archaeologies of the Spanish Civil War. Public Archaeology 6(4):203-26.

Henshaw, Jonathan

2012 Beyond Collaboration and Resistance: Accommodation at the Weihsien Internment Camp, China, 19431945. In Cultural Heritage and Prisoners of War: Creativity behind Barbed Wire, Gilly Carr and Harold Mytum, editors, pp. 152-167. Routledge, New York, NY.

Horning, Audrey J.

2006 Archaeology, Conflict and Contemporary Identity in the North of Ireland: Implications for Theory and Practice in Comparative Archaeologies of Colonialism. Archaeological Dialogues 13(2):183-200.

Jasinski, Marek E.

2013 Reinforced Concrete, Steel and Slaves: Archaeological Studies of Prisoners of World War II in Norway-the Case of Romsdal Peninsula. In Prisoners of War: Archaeology, Memory, and Heritage of 19th- and 20th-Century Mass Internment, Harold Mytum and Gilly Carr, editors, pp. 145-169. Springer, New York, NY.

Jasinski, Marek E., and Leiv Sem (editors)

2015 Painful Heritage: Studies in the Cultural Landscape of the Second World War, Skrifter 2015, Issue 4. Det Kongelige Norske Videnskabers Selskab, Trondheim, Norway.

Kewley Draskau, Jennifer

2012 Kulturkrieg and Frontgeist from behind the Wire: World War I Newspapers from Douglas Internment Camp. In Cultural Heritage and Prisoners of War: Creativity behind Barbed Wire, Gilly Carr and Harold Mytum, editors, pp. 201-215. Routledge, New York, NY.

Login, Emma L.

2015 Set in Stone? War Memorialisation as a Long-Term and Continuing Process in the UK, France and the USA. Archaeopress, Oxford, UK.

McAtackney, Laura

2011 Peace Maintenance and Political Messages: The Significance of Walls during and after the Northern Irish 'Troubles.' Journal of Social Archaeology 11(1):77-98.

McCrae, Robert R.

1984 Situational Determinants of Coping Responses: Loss, Threat, and Challenge. Journal of Personality and Social Psychology 46(4):919-928.

Moshenska, Gabriel

2006 Scales of Memory in the Archaeology of the Second World War. Papers from the Institute of Archaeology 17:58-68.

Moshenska, Gabriel

2008 Ethics and Ethical Critique in the Archaeology of Modern Conflict. Norwegian Archaeological Review 41(2):159-175.

Moshenska, Gabriel

2010 Working with Memory in the Archaeology of Modern Conflict. Cambridge Archaeological Journal 20(1):33-48. 
Myers, Adrian T.

2008 Between Memory and Materiality: An Archaeological Approach to Studying the Nazi Concentration Camps. Journal of Conflict Archaeology 4(1\&2):231-245.

Mytum, Harold

2011 A Tale of Two Treatments: The Materiality of Internment on the Isle of Man in World Wars I and II. In Archaeologies of Internment, Adrian Myers and Gabriel Moshenska, editors, pp. 33-52. Springer, New York, NY.

Mytum, Harold

2012 Photographs at Douglas Camp: Deciphering Dynamic Networks of Relationships from Static Images. In Cultural Heritage and Prisoners of War: Creativity behind Barbed Wire, Gilly Carr and Harold Mytum, editors, pp. 133-151. Routledge, New York, NY.

Mytum, Harold

2013a Loyal yet Independent: Archaeological Perspectives on Remembering and Forgetting World War I on the Isle of Man. In Engaging the Recent Past, Society for Post-Medieval Archaeology Monograph 7, Chris Dalglish, editor, pp. 35-53. Boydell \& Brewer, Woodbridge, UK.

Mytum, Harold

2013b Materiality Matters: The Role of Things in Coping Strategies at Cunningham's Camp, Douglas during World War I. In Prisoners of War: Archaeology, Memory, and Heritage of 19th- and 20th-Century Mass Internment, Harold Mytum and Gilly Carr, Mytum, Harold editors, pp. 321-332. Springer, New York, NY.

2013c Prisoner of War Archaeology in an Interdisciplinary Context. In Prisoners of War: Archaeology, Memory, and Heritage of 19th- and 20th-Century Mass Internment, Harold Mytum and Gilly Carr, editors, pp. 321-332. Springer, New York, NY.

Mytum, Harold

2015 The Archaeology of Modern Conflict: Ethics, Theories, Methodologies. In Painful Heritage: Studies in the Cultural Landscape of the Second World War, Skrifter 2015, Issue 4, Marek Jasinski and Leiv Sem, editors, pp. 7-16. Det Kongelige Norske Videnskabers Selskab, Trondheim, Norway.

Mytum, Harold, and Gilly Carr (editors)

2013 Prisoners of War: Archaeology, Memory, and Heritage of 19th- and 20th-Century Mass Internment. Springer, New York, NY.

Nagata, Donna K., and Wendy J. Y. Cheng

2003 Intergenerational Communication of Race-Related Trauma by Japanese American Former Internees. American Journal of Orthopsychiatry 73(3):266278.

Persson, Maria

2014 Materialising Skatås. In Ruin Memories: Materialities, Aesthetics and the Archaeology of the Recent Past, Bjørnar Olsen and Póra Pétursdóttir, editors, pp. 435-461. Routledge, London, UK.
Query, William T., Jim Megran, and Gary McDonald

1986 Applying Posttraumatic Stress Disorder MMPI Subscale to World War II POW Veterans. Journal of Clinical Psychology 42(2):315-317.

Roxworthy, Emily

2008 The Spectacle of Japanese American Trauma: Racial Performativity and World War II. University of Hawaii Press, Honolulu.

Sennett, Richard

2012 Together: The Rituals, Pleasures, and Politics of Cooperation. Yale University Press, New Haven, CT.

Shackel, Paul A.

2004 Labor's Heritage: Remembering the American Industrial Landscape. Historical Archaeology 38(4):44-58.

Shew, Dana Ogo, and April Elizabeth Kamp-Whittaker

2013 Perseverance and Prejudice: Maintaining Community in Amache, Colorado's World War II Japanese Internment Camp. In Prisoners of War: Archaeology, Memory, and Heritage of 19th- and 20th-Century Mass Internment, Harold Mytum and Gilly Carr, editors, pp. 303-317. Springer, New York, NY.

Silliman, Stephen

2001 Agency, Practical Politics and the Archaeology of Culture Contact. Journal of Social Archaeology 1(2):190-209.

Slaughter, Michelle A.

2013 An Archaeological and Ethnographic Examination of the Acquisition, Presence, and Consumption of Saké at Camp Amache, a World War II Japanese Internment Camp. In Prisoners of War: Archaeology, Memory, and Heritage of 19th- and 20th-Century Mass Internment, Harold Mytum and Gilly Carr, editors, pp. 285-301. Springer, New York, NY.

Somerfield, Mark R., and Robert R. McCrae

2000 Stress and Coping Research. Methodological Challenges, Theoretical Advances, and Clinical Applications. American Psychologist 55(6):620-625.

Ulmschneider, Katharina, and Sally Crawford

2013 Writing and Experiencing Internment: Rethinking Paul Jacobsthal's Internment Report in the Light of New Discoveries. In Prisoners of War: Archaeology, Memory, and Heritage of 19th- and 20th-Century Mass Internment, Harold Mytum and Gilly Carr, editors, pp. 223-236. Springer, New York, NY.

Ursano, Robert J., and James R. Rundell

1995 The Prisoner of War. In War Psychiatry, Franklin D. Jones, Linette R. Sparacino, Victoria L. Wilcox, Joseph M. Rothberg, and James W. Stokes, editors, pp. 431455. Office of the Surgeon General, Falls Church, VA.

Vischer, Adolf L.

1919 Barbed Wire Disease: A Psychological Study of the Prisoner of War. John Bale, London, UK.

Williams, Howard

2014 Monument and Material Reuse at the National Memorial Arboretum. Archaeological Dialogues 21(1):77-104.

Zeiss, Robert A., and Harold R. Dickman

1989 PTSD 40 Years Later: Incidence and PersonSituation Correlates in Former POWs. Journal of Clinical Psychology 45(1):80-87. 